FOLIA SCANDINAVICA

VOL. 18 POZNAŃ 2015

DOI: $10.1515 /$ fsp-2015-0018

DE DE GRUYTER OPEN

PRESSto. IMU. Adam Mickiewicz University Repository

\title{
LITERATURE
}

\section{THE ETHICAL TURN IN THE EARLY WRITINGS OF PÄR LAGERKVIST}

\author{
KATARZYNA SZEWCZYK-HAAKE
}

Adam Mickiewicz University in Poznań

ABSTRACT. In the text presented, I have undertaken an analysis of the early essays of Pär Lagerkvist (dated 1915-1917), both the ones published in periodicals and the unpublished manuscripts in the possession of the Kungliga Biblioteket in Stockholm. In those essays, Lagerkvist paid considerable attention to the matters of the ethics of art and the conflict between the ethical and aesthetical criteria of assessment of the work of art, and those problems are discussed also in Lagerkvist's letters from that time. The aim of the article is to present this less known area of the artist's activity and to point to the fact that the consequences of those reflections can be tracked in Lagerkvist's literary works written in the same time period. Moreover, it can be argued that the understanding of the ethical art and the moral sense of the artistic activity presented in the early texts became an import and lasting feature of Lagerkvist's writing - and, consequently, it can be claimed that the essays under discussion have a formative effect on Lagerkvist's later output.

\section{LEAVING THE SALON}

Around 1915, when the works establishing Lagerkvist's position as "the first Swedish expressionist" (Ek, 1918) were published, namely the prose collection 'Järn och människor' [Iron and men] (1915), shortly followed by the 'Ångest' [Anguish] tome of verse (1916), one notes a distinct increase in interest on Lagerkvist's part in the question of the ethical value of art, as expressed in his critical texts and letters. Among his manuscript notes and sketches, we find such titles as 'Konstens etik' [An ethics of art], 'Om betydelsen av en dålig konst och Om döden' [Of the meaning of bad art and Of death] and 'Om nödvändigheten av någon etisk begåvning hos konstnären' [Of the need for ethical talent in the artist], and ethics is addressed not just in texts where it is announced in the title. In some contexts, the subject 
of ethical art is linked to considerations of the spiritual aspect of modern life, easily (and wrongly) overlooked by art. This approach to reality and to artistic creativity, from the angle of its spiritual dimension, is clearly manifest in a letter to Nils von Dardel (16 November 1915):

Jag tror att den moderna konsten, om den inte skall förtorka, måste börja känna hängivnare, innerligare och att den måste gripas av mystiken som ligger tung och ljuvlig över livet - över det moderna livet djupare och tyngre an någonsin, ty för varje dag blir oss tillvaron allt större och mera ofattbar. (Lagerkvist 1991:60-61)

[I think that modern art, if it is not to wither, must begin to feel with more intensity, more internally, and must let itself be swept away by mystique, which lays itself, heavy and intoxicating, upon life - upon modern life - more deeply and heavily than ever, since with each passing day our environment becomes bigger and more unfathomable. $]^{1}$

In striving to render justice to the modern world in a modern language, the artist is forced to admit that the world cannot be explained by means of science and technology or other ways of rationalising it. The trends in modern art that the Swedish writer had hitherto valued highly, cubism especially, although fulfilling their function of expressing the truth about the role of 'construction' and 'organisation' in the life of modern man, were not effective for describing the whole of the phenomenon, since they were incapable of grasping the aura of mystery and uncertainty that characterises modern life - an aura in which Lagerkvist was showing an increasingly distinct interest (Karahka, 1975:22). ${ }^{2}$ In the sketch 'Om konsten. Några reflektioner' [Of art. A few reflections], Lagerkvist asked rhetorically: "Klarhet och mystik, mänsklig vilja och en obotlig skepticism pa bottnen av varje tanke, varje föresats - ar inte detta tidens väsen?" (Lagerkvist, 1916a:72) [Clarity and mystique, human will and boundless scepticism underlying every thought, every intention - is that not the essence of the times?].

In further articles, the writer, moving towards a definition of the meaning of art, drew the category of 'verity', as ethically conceived, increasingly distinctly into the sphere of his interests, setting aside questions of form and composition. One might assume that such a gesture would not have come easy to a recent advocate of the cubist avant-garde, although, as can be seen from the slightly later text (probably dating from the turn of $1917^{3}$ )

${ }^{1}$ English translation - John Comber, Katarzyna Szewczyk-Haake.

2 Urpu-Liisa Karahka, however, termed this period in Lagerkvist's oeuvre quite unequivocally 'aesthetic' (Karahka, 1978). In the present article, I point to the need for that assessment to be modified.

${ }^{3}$ The manuscript is not dated. The proposed dating is based on information contained in a letter to Edvard Hald (18 January 1917), in which Lagerkvist informs him that one of the two planned articles on the meaning of bad art is ready (Lagerkvist, 1991:74). 
'Om betydelsen av en dålig konst. Några stilla ord' [Of the meaning of bad art. A few quiet words], he did not find it as difficult as we might suspect:

Även jag finner det obildat att i ett bildat sällskap då samtalet faktiskt rör sig om estetiken plötsligt införa begreppet etik. Men har jag att välja mellan att blott och bart stå som exponent för gängse kultur och höja mig till den verkliga orginaliteten, väljer jag naturligtvis det senare. (Lagerkvist, KB L 120:79:2)

[Even I consider it ill-mannered, in well-mannered society, when the conversation concerns aesthetics, to suddenly interject the expression 'ethics'. However, were I to choose between proclaiming that which is commonplace in culture today or approaching true originality, then I would obviously choose the latter.]

Yet Lagerkvist hesitates over assuming the role of a champion of ethical values in art, probably still having in mind the aesthetical criteria he used to distinguish between the true and the popular art - only some years before ${ }^{4}$. He is aware that it is a rather unspectacular role, and in the eyes of a reader who is sensitive to forms of utterance it additionally burdens the author with the transgression of 'crudeness', which the insistent adherence to particular words and thought patterns represents:

Något bondskt och dumt vidlåder likväl alltid en moralist: särskilt då han ännu är dilettant på området. Och läsaren skall väl knappast kunna undgå att lägga märke till hursom i det nedanstående, själva orden gång på gång blir klumpiga och fadda.

Av konstnären fordrar man idag ett enda: att han skall göra god konst. Man frågar inte: med vilka medel? Med vilka eftergifter, vilka förvanskningar, förskjutningar av sanningen, med vilken förstoring av sin egen obetydlighet, med hur många timmar poserande inför sig själv? Blott ett: med vilken artistisk framgång? (Lagerkvist, KB L 120:79:2)

[The moralist always evinces something crude and stupid, especially if he is still a dilettante in the particular field. And the reader cannot fail to notice how words [repeated] time after time become ponderous and vain.

Today, the only thing demanded of an artist is that he produce good art. No one asks by what means? at the cost of what concessions, what deceptions, what bending of the truth? What magnification of his own insignificance, how many hours acted out for himself? Only what is the artistic success? ]

This passage, in which Lagerkvist - as if 'testing the water' - assumes the mission of a moralist within the ranks of the literary critics, reveals at least one conviction that is worth remembering and that can be easily linked to the

\footnotetext{
${ }^{4}$ Such distinction is put forward in 'Ordkonst och bildkonst. Om modärn skönlitteraturs dekadans - Om den modärna konstens vitalitet' ['Literary art and pictorial art: on the decadence of modern literature - on the vitality of modern art'] (Lagerkvist, 1913b; Chojecki, 1986:XXI).
} 
artist's ethics proclaimed through expressionism (Sokel, 1964:102-157). For Lagerkvist, the artist is above all - and contrary to age-old convictions, upheld by most avant-garde trends - 'insignificant', and the intentional departure from that state of affairs, triggered by the need to aspire to 'artistic success', is something highly burdensome, from the perspective of both the artist's life and also the ethical value of the works he creates. The need to come down on the side of either moral art (thereby lowering one's aspirations to elite, high art) or refined art (at the cost of communicativeness and the possibility of reaching 'all' receivers, with one's ethical convictions) was one of the key dilemmas of literary expressionism. In his notes, Lagerkvist touches on this very problem, although he elaborates on it, as we will see, in his own peculiar way. In this paper I'll try to follow his reasoning, which leads him from the initial distinction between 'good art' and 'bad art' (based upon aesthetical criteria) to acknowledgement and appreciation of a 'third kind' of art - the one composed with a true aesthetical care but at the same time revealing a a truth about human (i.e. - writer's and reader's) spiritual nature. Such literature can be aptly called ethical, since it responses to human ethical needs, although at the same time it is far from formulating any moral programme. The turn towards such art I'm going to refer to as 'ethical', not because of any philosophical or religious values causing it, but because it is a result of an uncompromising ethical quest, which has became an important feature of the whole Lagerkvist's œuvre.

\section{THE AMBIVALENT MEANING OF BAD ART}

The quoted text is rather more a collection of notes than an ordered exposition, and we do not find in it the clear and consistent line of reasoning. There are many conditional forms and hesitations, plenty of evidence of his search for the right language to express what is truly essential and what he regards as correct. Some of the difficulties with which Lagerkvist wrestles are due to the fact that he is attempting to reconstruct his thinking up to that point, formed in part by the aesthetic categories of modernity (the avant-garde postulates of cubism), using to some extent the descriptive tools proper to those categories. It is significant that in the title of the text he places the unequivocally sounding term "bad art", making that classification from the position of a modernist theorist and critic, whilst the titular epithet refers in the text to works that do not follow the fashionable trends in modern art and do not try to achieve self-fulfilment in a formal tour de force. At the same time, he clearly distances himself from the criteria of assessment to which contemporary modish criticism adheres, forcibly stressing his own point of view in the text 'Om betydelsen av en dålig konst och Om döden': 
Sannerligen: vi ha på ett ödesdigert sätt kommit långt bort från det som ensamt kan befordra det estetiska livets sundhet och fördjupning: respekten för dålig konst. Vi ha gått så långt att vi icke blott förneka konstnärens plikt att göra dålig konst men till och med hans rätt därtill. (Lagerkvist, KB, L 120:79:2)

[There is no denying that we have fatally distanced ourselves from what may, in itself, support the health and depth of aesthetic life: respect for bad art. We have gone so far that we negate not only the artist's obligation to create bad art, but even his right to do so.]

The distance with regard to the 'salon' is evident in many sketches from this period in which Lagerkvist writes with irony about the blind aspiration to originality and the submission to the rituals of artistic life that characterise the modern artist and are fuelled by the critics (Löwendahl, 1975) ${ }^{5}$. Against this background, it is easier to comprehend the need for a return to 'bad' art, as an important and invigorating alternative. Its significance, sought by Lagerkvist, is by no means trifling. In the text 'Om betydelsen av en dålig konst och $\mathrm{Om}$ döden', Lagerkvist grants bad art an exceptional ability - the most crucial ability that art in general can obtain:

Medan konstens betydelse över huvud kanske är något tvivelaktig finns det alls intet tvivel om att den goda konsten i varje fall ingen som helst betydelse har vare sig för mänskligheten eller den enskilde; den dåliga däremot förmår åtminstone i vissa stunder höja våra hjärtan till ödmjukhet och ängslan - och vad är större än så? (Lagerkvist, KB L 120:79:2)

[Although the significance of art is in principle something dubious, there is no doubt that good art has no significance either for humankind or for a single person, whereas bad art, at least at certain moments in time, is capable of lifting our hearts to humility and anxiety - and what could be greater than that?]

The categories evoked here indicate that resistance to the dogmas of the 'salon' is not the only virtue of bad art; it is credited above all with stirring essential emotions and feelings in man. The assertion that humility and anxiety are the 'greatest' feelings is significant, as it points unequivocally to a system of values that sees virtue in 'smallness' and a path to perfection in spiritual suffering - burdensome for art, but undoubtedly close to a communionist type of expressionism. The same evaluation is manifest in a passage in which Lagerkvist levels an important accusation at 'good' modern art, charging it with the falsification of the image of human existence and the inability to

${ }^{5}$ The variants of this article discussed by Löwendahl, titled 'Om betydelsen av en dålig konst' [Of the meaning of bad art] and 'Konstens etik' [An ethics of art], differ from the copies held in the KB. The text clearly had several variants, which testifies the weight of this issue for the writer. Löwendahl quotes short passages that show the concordance of opinions on "salon art' in all the essays. (Löwendahl, 1975:120f.) 
represent its real and crucial dimensions. It goes without saying that the line of attack on modernist art - at the same time a line of defence for 'bad' art - is based on ethical questions:

För det stora och praktfulla i mänskligt lidande synes mig den moderna konsten ha funnit vackra och varaktiga uttryck. Däremot icke för lidandet. (Lagerkvist, KB L 120:79:2)

[For that which is grand and noble in human suffering, modern art has found, in my opinion, beautiful and enduring expression. But not for the suffering itself.]

Here, Lagerkvist calls for human suffering to be made an object of art's attention, without elevating it and thereby transferring it into artistically recognisable and assimilated areas - a falsification of the crucial dimension of human existence that characterises, in the writer's opinion, self-styled modern art, although not that alone. At one point, he generalises: 'good' art, of both modern and earlier times, always has the same sins on its conscience:

Egentligen har jag nu alls ingen lust eller behov att uppehålla mig särskilt vid vad vi vant oss vid att benämna den modärna konsten, ty denna är ej avsedd att i högre grad än varje annan art av god konst träffar av de mina anmärkningar som befinner riktiga. (Lagerkvist, KB L 120:79:2)

[At present, I do not really have the desire or the need to dwell in particular on what we are accustomed to calling modern art, since my remarks would not appear to concern it to a greater degree than any other kind of good art.]

So the division into good and bad art is timeless, and the crusade against good art does not amount to an attack on spectacular but short-lived artistic fads. It clearly concerns something more, namely the truth about man and the possibility of expressing that truth in a work. In the opinion of Lagerkvist, the crucial dimension of the 'ethics' of art was not the creation of an illusion, but the sober, honest articulation of the drama of human fate, treated in a very serious way. In the sketch 'Konstensetik' [The ethics of art], ${ }^{6}$ he wrote:

Det kan aldrig vara riktigt detta, att konsten är något så utomordentligt. Att den visar människans överlägsenhet $\mathrm{i}$ några få extatiska stunder av liv över livets intighet. Den visar väl mer när den är stor och verklig, hennes underlägsenhet under ett öde som hon inte kan fatta och ännu mindre betvinga. (Lagerkvist, KB, Lagerkvist, 1978/82)

\footnotetext{
${ }^{6}$ This text is not dated; the rest of the material in the file is from the end of 1915 and the beginning of 1916, and on that basis we may assume that this sketch was written around the same time.
} 
[After all, it is not entirely true that art is something exceptional, that it shows man's supremacy, in the few ecstatic moments in life, over the nothingness of life. For it shows more when it is great and true: its subjection to fate, which it cannot comprehend, let alone suppress.]

Thus the importance of bad art, capable of approaching the truth about human fate, is great, both for the beholder and for the artist. The former has the chance to 'rise towards humility and anxiety', whilst the latter can honestly express his own existential disquiet:

Detta är något som bör sägas: Den goda konstens grundförutsättning ar oärlighet i känslolivet. Den dåligas: ärlighet och ångest. (Lagerkvist, KB L 120:79:2)

[It must be said: a fundamental condition of good art is dishonesty in emotional life. Of bad art - honesty and angst.]

As we can see, the criterion of honesty as a variant of the 'truth' of the work plays a significant role in the writer's views on the value of the work, although he did not deem it sufficient in itself. The quoted sketches, differing in their subtitles, bear the common main title 'Of the meaning of bad art' (emphasis $\mathrm{KSH}$ ), and that is an apt title, since in pursuing the rehabilitation of honest art Lagerkvist is far from affirming it uncritically. It would seem that besides hisenduring attachment to the imperative of working on the formal aspect of the work (cf. earlier remarks on the unmasked evaluation hidden in the epithet of bad art), Lagerkvist is restrained from the glorification of bad art by an awareness of the fine line between feelings honestly expressed, on one hand, and ideological or programmatic solutions arising from those feelings, on the other. So he considers a whole number of issues connected with the essence of the truth of the artwork and the place of the (moral, religious, etc.) truth of the worldview proclaimed by the artist through his work. We may state for certain that the antipathy towards 'dishonest' art is not confined solely to works which provide the receiver with sublimated suffering instead of the expression of suffering, masking falsification with artistic refinement. In another sketch ('Om betydelsen av en dålig konst'), Lagerkvist distances himself clearly from works that, raising form to perfection, prevent us from nearing the truth about existence and with their dazzling character falsify our way of thinking about the sense of artistic activity. In effect, the very term 'art' is untrustworthy, since the works to which it is most often applied do not approach the truth about existence, which is bound up with ordinariness, discouragement and anxiety:

Konsten! Själva ordet är för övrigt löjligt. Det ger en fadd och sötaktig smak i munnen när det uttalas. Det är därför att det nästan genom hela tiden sockrats med så mycket glädje. Färg och ord ha strålat i rikedom och prakt. Om det torftiga mörkret kan ordet nästan inte brukas. Och jag vill söka att undvika det. (Lagerkvist, KB L 120:79:2) 
[Art! The very word itself is essentially ridiculous. It leaves an insipid and sweetish taste in your mouth when you utter it. That is because it has been embellished the whole time with enormous joy. Colours and words have radiated richness and lavishness. The word is all but redundant in relation to desolate darkness. And I want to try to avoid it.]

It must be remembered that when writing about 'bad art' Lagerkvist is wrestling with the problems that are most essential for him, and the titular term is essentially pseudonymous with his own output from that period. When he writes that the conditions for bad art are 'honesty and angst' ('ärlighet och ångest') in emotional life ('i känslolivet'), it is difficult not to associate this with passages from letters in which he employs the category of honesty to define his own writing (Lagerkvist 1991:70) or suggests that 'Järn och människor' is a book that he wrote 'from himself' (Lagerkvist 1991:60), in which 'nothing was made, but everything sprang from concentration and joy at work' (Lagerkvist 1991:61). Yet the question of the value of tendentious literature was a crucial one for Lagerkvist; after all, at that time he was still working with left-wing periodicals (Stormklockan, Fram, Första Maj), and some of the texts published there certainly merit such a name (Larsson 1964:36). And it may have been that personal dimension to the notes that made him refrain from publishing them, also affecting the difficulty he had with making an unequivocal critical gesture; consequently, bad art, although its status was enhanced, remains bad art, whilst good art, although profoundly criticised, is not given another name. The lack of consent to the existence of an axiological hierarchy in literary criticism does not make it any easier to find other criteria, since the way is clearly blocked by a fear of turning literature and art into an arena of campaigns and disputes over worldviews. The deadlock remains.

\section{ON THE TRAIL OF A 'THIRD KIND’ OF ART}

At one point in his deliberations, however, Lagerkvist defines also the kind of art that appears to interest him the most - a variety of ethical art. The following passage is sufficiently interesting to be quoted in extenso:

För övrigt är det en sak jag har svårt [att] låta bli att tänka på. Den nämligen: om det inte egentligen snart borde vara på tiden att säga något föraktligt om konsten över huvud? Men varje gång jag skall till med det, hejdar jag mig plötsligt; ty jag påminner mig att det existerar ej blott dessa två arter av konst: dålig och god, men därtill även en tredje som är upphöjd över båda dessa begrepp. $\mathrm{Nu}$ kan det måhända ifrågasättas om denna tredje art egentligen faller under den löjliga benämningen av konst, då ens källor ju framspringer ur en värld helt olik och långt fjärran från den som med sin trånghet och smånätta lustighet tillåter varje liten artistisk fantasi att briljera med små nätta syner och upptäckten av några kosmiska proportioner. (Lagerkvist, KB L 120:79:2) 
[In addition, there is one question that troubles me when I ponder it, namely would it not be more in keeping with the spirit of the times to express contempt for art per se? Yet each time I am about to do so, I suddenly stop, since I remind myself that there exist not just those two kinds of art, good and bad, but also a third kind, over and above those two expressions. Now perhaps we may question whether this third kind is at all subject to the absurd name of art, since it issues from a world that is utterly dissimilar and far-removed from the one that in its narrowness and pretty-pretty ridiculousness allows every little artistic fancy to cut a dash with a graceful vision and revelation of cosmic proportions.]

In this way, on the path to the complete invalidation of the existing aesthetic division into good and bad art, or rather the parenthesising of its entire domain, a resolution can be achieved. We may hesitate over whether that resolution is of an artistic or an existential character. In declaring himself in favour of a 'third kind', Lagerkvist questions whether it would be right to call it 'art', since its essence is far from artistic criteria. With regard to activity of this sort, the postulate 'Det är som människa jag är konstnär' [It is as a person that I am an artist] (Löwendahl, 1975:120), essentially expressionist in spirit, is actualised entirely, since it is in works produced in this 'third' way that the honesty of utterance guarantees the simultaneous expression of the truth, on account of the 'sources' from which it arises. As for the world from which that 'third', and only valuable, kind of art arises, we know only that it is similar to neither the world governed by changing aesthetic criteria nor the world of individual emotionality, which easily descends into blindness.

Here too Lagerkvist does not articulate his idea to the end; if he had, then he would have proclaimed a ready-made metaphysical truth - a step that he never took. Nevertheless, the direction taken by his reflection is perfectly clear. In the passages quoted by Löwendahl from the Lund manuscripts, we read that valuable art is art that 'has something to say to man' ['har något att saga själva människan'], from which grows 'the flower of eternity' ['evighetsblomma'] (Löwendahl, 1975:121). However we might wish to clarify that 'distant world' (and every 'clarification' would tend rather to obscure the writer's intentionally elliptic idea more than elucidating it), the very awareness of its existence bestows upon a person the opportunity of perceiving his life in a dimension that is broader than his own here and now, and thanks to art that awareness is gained by both the artist and the receiver. Only in this way, setting aside deliberations of good and bad art, can the artist address the task of expressing in his work the truth about 'livsmystik': then, the positive value of his work will lie not or not just - in its aesthetic values or in the hope borne by the proclaimed ideology, but in the very fact that he has turned to that which determines the depth and weight of human existence: to its spiritual layer. And in that 
sense the showing and transmitting of the truth about 'livmystik' may be couched in terms of the moral obligation that is incumbent on the artist. Be that as it may, we are dealing here with the truth about human existence and also about something else: the support which the receiver may (or may not) gain from literature - support that is understood, let us reiterate, not as fortification through the suggestion of a particular worldview, but as a signpost to the spiritual world, extending above the reality familiar from everyday life and enabling us to confront our existence, which consequently acquires a higher meaning. ${ }^{7}$ Lagerkvist's own output - both that from the period which scholars refer to as 'livstro' and that from the later period of 'Det besegrade livet' ['The defeated Life'], characterised by revolt and activism - remains within the sphere of ethical art as understood

${ }^{7}$ Henceforth, Lagerkvist will proclaim quite consistently the view that 'ethical' literature should hold up a model of a certain existential attitude involving accepting life as it is and facing up to it, and not a ready-made axiology or morality: it will mark both his opinions on other artists and also his own work. An instructive task in this context is observing how Lagerkvist's views on Fyodor Dostoevsky evolved. In an early review of a new Swedish translation of 'The Insulted and Injured' (pub. 1913 as 'De förtrampade'), he expresses the view that the Russian writer's mastery is attested by the fact that he deeply moves the reader despite evident flaws of composition and form (Lagerkvist, 1913a - see also Karahka, 1978, pp. 83). Less than a decade later, in a letter to August Brunnius of 1922, in which he refers to the addressee's article on Dostoevsky, he reveals completely different criteria of judgment:

'Oredan och schablonen i hans framstallning har alltid ocksa stött mig. Likval ar det ju ett bevis pa hans andes väldighet hur litet allt detta betyder, många är inte de som skulle tåla vid sadant. Och jag tycker ej att det är nagot nedslående $i$ att man i var tid kan med hull och hår anamma en forf. med denna ej smakligt tillrättalagda form - tvärtom, det tycks mig glädjande och sunt. Men nedslående att orsaken oftast ligger i vurmen för det sjukliga och överspända. Laste jag nu om honom tror jag inre formlösheten skulle störa mig mycket, men väl det överhettade och förpinta i hans mänskor och inne i honom själv. Nej, jag vill bli vid med att läska mig ur anrda källor. Man kan ju förklara för sig varför han just nu är så livligt eftersökt, ty vi söker ju tyvärr inte de makter som kan hjälpa och frälsa oss men dem som ännu ytterligare kan styra förnimmelserna av det som är. Men utan tvivel vi borde vända oss till andra gudar.' (Lagerkvist, 1991:206)

[I was also always bothered by a certain lack of order and triteness in his manner of depiction. At the same time, however, just how little that really matters is evidence of his spiritual greatness, since few writers could get away with it. Neither do I consider that there is anything depressing in the complete acceptance in our times of a writer whose form is not tastefully prepared; on the contrary, that seems to me invigorating and healthy. What is depressing, however, is the fact that the reason lies most often in [his] mania for everything sick and oversensitive. Were I to read it again now, I doubt that I would be particularly bothered by the lack of form, but rather by the feverishness and anguish in his protagonists and in him. No, I prefer to slake my thirst in other streams. It is understandable that he is so keenly read precisely at the present time, since we are seeking, unfortunately, not those powers that can help us and cure us, but those that are even more apt to steer our perception of what is. Unquestionably, however, we should be turning to other gods.]

This example of Lagerkvist's opinion of Dostoevsky shows that the changes discussed in the present article - what I call his 'ethical turn' - became a lasting trait of his theory of art, cultivated most consciously in defiance of the 'times' and of the expectations they proclaim. 
in the following way: it shows first and foremost the existential situation of man, particularly susceptible in the modern world to the loss of his awareness of "what is spiritual'.

\section{TRACES OF A TURN IN LAGERKVIST'S OWN OUTPUT}

Lagerkvist did not publish, and did not even finish, those theoretical texts on art which place questions of ethics to the fore; in his published critical texts from that time, ethical issues, although present in the background, do not occupy a prominent place. One may gain the impression that he wished to consider them primarily for his own purposes. In Lagerkvist's works from that time, meanwhile, and also - at least just as crucially - in his own commentaries to them, we can detect clear traces of an analogous 'ethical turn'. With regard to the book 'Järn och människor' [Iron and men], he wrote to Ellen Key (11 November 1915):

Jag har skrivit denna boken $\mathrm{i}$ en annan stämning än den i vilken jag skrev 'Motiv'. Jag har försökt att bli litet ödmjukare och litet mindre självsäker. Jag har forsökt offra litet av den koketta ateljéjargongen och istället inför gestalterna som jag sökt forma känt och gripits främst som människa. Därför har givetvis inte min tilltro till de konstnärliga principer jag förut hyllat på något sätt rubbats. Men principer är ju ingenting annat än en byggnadsställning, löjlig att resa om man inte också verkligen tänker bygga ett hus, inom vars murar människor kunna värma sig och komma varandra nära. (Lagerkvist, 1991:60)

[I wrote this book in a different mood to that in which I wrote 'Motiv' ['Motif']. I tried to be a bit more humble and less self-confident. I also tried to sacrifice a little of that wheedling jargon of the trade and to introduce instead characters formed in such a way that they be sensed and engaged with first and foremost as people. Hence, of course, the faith in the principles of art that I earlier confessed has not waned within me. Yet principles are nothing more than scaffolding; it is ridiculous to erect it if one has no notion of building a home in which people can warm themselves and warm to one another.]

The metaphor used by Lagerkvist towards the end of this passage is significant and speaks more about his attitude than a longer theoretical exposition could have done. Principles and rules of creative work are important insofar as they allow one to achieve the basic goal of creating the

\footnotetext{
${ }^{8}$ In this sense, this output may be regarded as thoroughly suffused with the overriding idea of expressionism, attempting to express the spiritual in defiance of the civilisational processes of modern life (Vattimo, 2006:32f.). At the same time, it is also worth pointing to distinct analogies of thinking between Lagerkvist's reflection and only slightly later remarks, arising from a similarly expressed experience of dehumanisation, made by José Ortega y Gasset (1996:191-220).
} 
work, that is, to forge a place where the receiver will be bolstered and uplifted. Thus the artist's ethical stance is not reduced to any specific ideological content made explicit in the work, but involves rather an attitude towards existence that precedes the writing of the work. Expressed in words, that attitude easily descends into one worldview or another; in essence, it boils down to what Lagerkvist deftly described using the metaphor of 'building a home' - devoid of the ideological foundations of activism and communionism.

That is the context in which I would like to situate a reading of one of Lagerkvist's poems written at exactly the same time as the unfinished essays on the ethical dimension of art, a later variant of which was included in the tome 'Ångest' as an untitled poem with the incipit 'Människor, människor...'

The poem 'Caféinteriör' is written in the same notebook that includes the sketch 'En ny tid och en ny konst' ['A new time and a new art'], which concerns the questions under discussion.

Människor, människor. Varmt och ljust.

Utanför faller tung snö.

Heta drycker pa marmorborden stå, heta små ådror i kropparna gå, ur människornas hjärtan de ila att genom deras händer sila.

Små små tankar irra kring, söka ingenting,

längta ingenting.

Men utanför star rymden, och i dess blåa ring stjärnorna de lysa som pärlor.

Tänken små tankar, människor små, stängen er inne djupt under rymdens blå, spiken rummen så trånga, sitten tillhopa många.

Ack utanför väggarnas heta guld står likväl natten, står kölden, stel och stum; och en gång den utkräver varje människas skuld till stjärnorna och mörkret och evighetens rum. Omätlig stort är att leva. (Lagerkvist, KB Lagerkvist 1978/82) $^{9}$

${ }^{9}$ This is immediately followed by another variant of the text, this time entitled 'Interiör' (with the date 22 December 1915), then one more, also under the title 'Interiör', not dated and very difficult to read. The changes between 'Caféinteriör' and the first version of 'Interiör' concern mainly the further 'deconcretisation' of the described place. The passage that is key to my analysis ("Och en gång den utkräves varje människas skuld / till stjärnorna och mörkret och evighetens rum.") is identical in both manuscript texts. 
[People, people. Warm and bright. / Outside a thick snow falls. / Hot drinks stand on marble tops, / In the bodies, hot veins move, / they rush from human hearts / to penetrate their hands. / Little, tiny thoughts go round, / not seeking, / not longing./ Yet outside there is space, and within its blue orb / stars shine like pearls. // Think little thoughts, little people, / shut yourselves in, deep beneath the blue expanse, / fill the room up tightly, / sit together, thronged. / Ah, beyond the walls' warm gold / the nightstands cold, numb and dumb; / one day it will demand the human debt / to the stars, the darkness and the everlasting space. // To live is infinitely great.]

The fact that we easily recognise in this poem the core of the lyric published in 'Ångest' (printed 23-29 November 1916 - Karahka 1978:207) results from the substantial similarities of construction, obscured by neither the 'deconcretisation' ${ }^{10}$ of the place described nor the minor formal change in the ending. That change, however, renders the meaning of the text diametrically different. In the printed poem ${ }^{11}$, we read:

Tänken små tankar, människor små, stängen er inne djupt under rymdens blå,

spiken rummen så trånga,

sitten tillhopa många.

Ack utanför väggarnas varma guld

står likväl natten, står kölden, stel och stum;

och en gång den skall gäldas varje människas skuld

till stjärnorna och mörkret och evighetens rum.

Omätlig stort är att leva.

(Lagerkvist, 1916b:28)

(Think little thoughts, little people, / shut yourselves deep beneath the blue expanse, / fill the room tightly, / sit together, thronged. / Ah, beyond the walls' warm gold / the nightstands cold, numb and dumb; / and one day it will pay the human debt / to the stars, the darkness and the everlasting space. // To live is infinitely great.)

The semantic change between 'och en gång den utkräver varje människas skuld' (will demand the debt) and 'och en gång den skall gäldas varje människas skuld' (will pay the debt) diametrically inverts the sense of the poem's ending: instead of a menacing space representing a gloomy memento for all human activities, we have an image of a space that arches mercifully over man, transcending him infinitely and understanding him. It would be

\footnotetext{
${ }^{10} \mathrm{NB}$ this tendency, as characteristic for Lagerkvist's works from this period, has already been noted (Karahka, 1992:117).

${ }^{11}$ This strophe is the same in a fair manuscript of the volume (Lagerkvist, KB L:120:70).
} 
difficult to speak here of the expression of a specific worldview in either of the variants of the text: in both versions, the key question is the anthropomorphisation of cold, dark space, anticipating its perception as friendly or hostile, and also the common conviction of man's indebtedness, a kind of inherent original guilt. At the same time, the later variant, tracing a picture of the justification of human life from the perspective of eternity, lends the poem's last words-"Omätlig stort är att leva" - a very lofty meaning, allowing us to believe in the sense of existence not just in defiance of the world, but in harmony with it.

\section{LITERATURE AND ART, AND THE QUESTION OF 'ETHICAL ART'}

By no means, however, would I wish to treat the later version as a variant prepared 'for the fortification of hearts'. I prefer to perceive Lagerkvist's work on this poem as evidence of a particular stage in his artistic development, the significance of which he described with reference to the works of Cézanne. In a sketch about his painting, we read:

Inför dessa kompositioner med människor ute i naturen som sysselsatte honom under hans sista period eller inför ett av dessa märkliga stilleben från samma tid står vi gripna av den känslan att vi skåda in i en ny värld och bevittna hur naturens och tingens dolda krafter bryta fram för att brottas med varandra. Ty det är en brottningskamp med en sådans hela dramatiska spänning vi bevittna - men konstnären behärskar alla de framstormande krafterna och avväger dem efter sin vilja. Därför fylles trots allt tavlan av harmoni. Ja, ingen modern konst förekommer oss vid första anblicken så lugn och behärskad som Cézannes, ehuru väl ej mycket är målat med en sådan brinnande lidelse. Det beror därpå att uttrycksmedlen äro så nobla, hela föredraget präglat av förfinad kultur. Färgackordet är av den största enkelhet och sprödhet och all brutalitet i formgivningen undviker egentligen denna de lössläppta krafternas målare. Det ligger som en lätt slöja över tavlan, vilket gör att vi blott så småningom ana hela vidden av konstnärens vision. (...) Först när vi trängt till djupet av verkets tanke förstå vi att det är ett tillkämpat lugn och att det stilla suset ur fjärran är ett ännu icke helt tystnat dån från striderna som stått. (Lagerkvist, 1915:20, emphasis $\mathrm{KSH})$

[We stand before these compositions depicting people in the space of nature, which occupied him during the last period, or before the remarkable still lives from the same period with the sense of beholding a new world and witnessing how the hidden forces of nature and of things reveal themselves in order to clash with one another. For what we are observing is a battle and its dramatic tension, although the artist masters the restless forces and weighs them according to his will. That is how the picture, in spite of everything, is full of harmony. No modern works seem at first glance so calm and composed as Cézanne, although few were painted in such great suffering. It is because the means of expression are so 
refined that the entire representation bears the hallmarks of sophisticated culture. The harmony of the colours is exceedingly simple and delicate, and this painter of unleashed forces avoids all brutality of form. That harmony rests on the picture like a veil, through which we sense only little by little the whole vigour of the artist's vision. [...] Only when we penetrate the idea of the work do we understand that this calmness is hard-won and that the soft murmur from afar is the rumbling of the recent battle, not yet entirely suppressed.]

Lagerkvist included in this passage a crucial part of his views on how art ought to be. Particularly essential would appear to be the words about the 'hardwon sense of calm', achieved through the artist's mastery of the suffering and contradictions that wrack him. It is thanks to that ability to combine unperturbed diction with a remembrance of former anxiety that Cézanne deserves to be hailed by Lagerkvist in the same text as 'one of the great educators of humanity' ('en av männsklighetens stora uppfostrare'). He himself did not wish to cross that threshold, aware as he was that the writer-educator, in contrast to the artisteducator, is condemned to the intermediary of words and easily becomes a slave to the philosophical, religious or social systems constructed on those very same words (Lagerkvist, KB L 120:49:1).His reflection on the correspondence of the arts and the essence of literary expression, cultivated since his early years, meant that Lagerkvist had a remarkably deep understanding of the issue of art ethics, in connection with the problem of the peculiarity of linguistic material. Long since convinced that the writer who is bound to the philosopher, theologian and historian by the linguistic material that he uses finds it difficult to achieve independence (Lagerkvist, KB L 120:49:1), ${ }^{12}$ with time Lagerkvist began to discern in that independence a condition for creating art that might have some crucial bearing on human existence. His ideal became ethical literature, apt to express at the same time the truth about imperfect human nature and about the human ability to perceive dimensions transcending man. At the same time, this is a literature that avoids ossified words and the worldviews expressed through them, which all too easily move away from human suffering, wishing rather to relieve suffering by showing man from the perspective of long since forgotten spiritual horizons of existence. ${ }^{13}$

${ }^{12}$ The early text to which I refer bears the title 'Om dikten och diktaren. Improviserade fantasier. Ur en ungs och ensams dag bok' and the date 12 August 1912 - 28 August 1912.

${ }^{13}$ A few years later (5 June 1918), Lagerkvist wrote in a letter to Ellen Key words that may be quoted as an apt summary of the path towards 'ethical literature' that I have described above, the aim of which is not facile consolement but equipping the reader with faith in the sense of activeness and the greatness of human existence:' 'Jag är ingen filantrop och min barmhärtighetskänsla inför mänskligt lidande är av en bestämd grund ganska liten: jag ser i lidanden som tynga individer och folk ingenting upprörande, men en naturens visa och milda ordning som tillåter det bästa och starkaste hos mänskorna att bryta fram (...). Därför tror jag heller inte och hoppas framför allt inte på ett himmelrike på jorden. Det ar kampen för detta som är allt, utan den kunna vi inte leva; stode vi därför en gång vid målet, så skulle världen rätt 
Urpu-Liisa Karahka (Karahka, 1992:106) rightly points to the evolution of Lagerkvist's lyrical practice during the 1910s, describing it in terms of a passage from a constructivist and intellectual aesthetic towards the need to 'account for the times' and ultimately to acknowledging the supremacy of feelings and perceiving the poem as a document of emotions (although never to a degree that would allow the role of the conscious construction of the text to be ignored). It would seem, however, that we will not have said everything about the inner changes in Lagerkvist's work at this stage in his oeuvre if we do not take into account the strongly manifested need to make the literary work a space for human closeness and a kind of asylum, and also the imperative of justifying the existence of the work in terms of its moral weight. If we return for a moment to the passage from 'Konstens etik' [An ethics of art] quoted at the very beginning, we can note a hesitation as to the exact status of art which appears to speak the most about man when it reveals his weakness, although it is not devoid of virtue when it draws attention to the 'ecstatic moments' of existence. The answer that Lagerkvist gives at the end passes over the content of the work understood as its plot or conceptual substance, since the key criterion of his assessment proves to be the ability to point to the spiritual element that is present in life - be it happy or tragic. This brings him close to expressionist literature. Distrustful with regard to an excess of aesthetic self-awareness and also to turning the work into a conduit for a ready-made worldview, in his own output he never resolved to play the role of educator, mentor or prophet, although he did approvingly attribute the first of those roles, as we have seen, to his adored Cézanne.

From this perspective, it would seem that the decision to remove some poems from the tome 'Ångest' as it was being prepared for print - and, as Karahka writes, the ones that were omitted in print were especially texts with a considerable emotional charge, personal, ecstatic eruptions of alarm, repulsion, yearning and horror - was not necessarily dictated by embarrassment at that which was personal (Karahka, 1978:216-217). One may just as well surmise that the key factor was the poet's conviction of the negligible value of those texts for the building of a 'common home', their uselessness, and possibly even injuriousness, for the project of 'ethical literature'.

Lagerkvist's self-awareness as an 'ethical poet' grew over time, as can be gauged from a letter to August Brunius of 25 November 1920:

\footnotetext{
plötsligt läggas platt och öde.' (Lagerkvist, 1991:92) [I am not a philanthropist, and my compassion for human suffering is for some reason rather limited; in the suffering that afflicts the individual or group, I see nothing moving, but rather the wise and gentle order of nature, which allows the best and strongest people to go forward [...]. Hence I do not believe, and above all I have no hope, in a heavenly kingdom on earth. The struggle for it is everything; without that, we could not live. So if we were one day to stand at the goal, the world would become all at once flat and empty.]
} 
Jag har ju alltid haft respekt for ditt omdöme om mitt arbete, men jag ska säga dig när jag fick verkligt stor respekt för det. Det var när du efter Kaos skrev till mig att jag i själva verket var moralist. Det har nämligen ingen annan sagt, fastän det är det etiska som ständigt upptar mig och inte konstmakeriet. Det skulle glädja mig om denna synpunkt också vid läsningen av min sista bok inte varit dig främmande, ty då tror jag du ser rätt. Det finns ju efter vad jag märker individer i fäderneslandet som anser mig som något slags estetforfattare, manikurerad och ängsligt modern, gud med dem. Det skall vara i det snusstuggande buslandet Sverige (det litterära, inte det verkliga!) som man, därför att man kanske har en smula känsla för form och balans, blir betraktad som estetflabb. (Lagerkvist, 1991:147-148)

[I have always felt respect for your appraisal of my work, but I shall tell you when I felt really great deference for it. It was when, after the publication of 'Kaos', you wrote to me that I was essentially a moralist. No one else made such a claim, although ethical issues, and not 'doing art', have occupied me continuously. I would be glad if you were to retain that opinion when reading my latest book, ${ }^{14}$ since I believe you are right. There also appear to be compatriots of ours who would see in me a kind of writer-aesthete after the modern fashion; God be with them. That is just how it is now in churlish, tobacco-chewing Sweden (the literary one, not the real one!), that anyone who has the slightest sense of form and balance is labelled an aesthete. ]

These last sentences may explain why Lagerkvist so vehemently attacked the aesthetic norms of the salons, unwilling to submit to their judgments. More importantly, however, he strongly internalised the not entirely recorded and unnamed criteria of 'ethical art'. The basic value of that kind of art, its inalienable role as a 'common home' for receivers prepared to undertake a spiritual quest, served Lagerkvist as the foundation of his own output over subsequent decades, long after the avant-garde disputes had fallen silent.

Sven Linnér (1954:18f.) points, albeit tentatively, to a connection between Lagerkvist's early poems and the late tome 'Aftonland' ['Evening Land'], and he suggests that a common denominator of the two is a conviction of the existence of a world beyond material reality. It is my opinion that the hypothesis may be advanced more boldly: during his youth, sensitive to questions relating to the theory of art and orienting his ideas towards the spiritual domain, Lagerkvist pondered many aesthetic and ethical questions. He treated the points shared by those two domains in an original way, albeit close in spirit to expressionist activism, and made focusing on them the enduring basis for his later output.

\footnotetext{
${ }^{14}$ The book in question is 'Det eviga leendet' [The eternal smile] (1920).
} 


\title{
REFERENCES
}

Chojecki, A. (1986). Wstęp. In: P. Lagerkvist, Wybór prozy (p.V-LXXXIV). Wrocław: Zakład Narodowy im. Ossolińskich.

Ek, S. (1918). Pär Lagerkvist, en svensk expressionistisk diktare. Litteraturen, p. 355-363.

Karahka, U.-L. (1975). Kring Pär Lagerkvists Ångest och den tyska expressionismen. Tidskrift för litterturvetenskap 1, p. 22-32.

Karahka, U.-L. (1978). Jaget och ismerna: studier i Pär Lagerkvists estetiska teori och lyriska praktik t.o.m. 1916. Lund: Caverors.

Karahka, U.-L. (1992). Pär Lagerkvists 10-talspoesi i ett internationellt perspektiv. In: Pär Lagerkvist 100 år. Föreläsningar och anföranden $i$ Växjö våren 1991. Pär Lagerkvists-samfundets skriftserie nr 1 (p. 97-124). Växjö: Pär Lagerkvist-samf.

Lagerkvist, P. (1913a). Dostojevski, De förtrampade. Stormklockan 15.02.

Lagerkvist, P. (1913b). Ordkonst och bildkonst. Om modärn skönlitteraturs dekadans - Om den modärna konstens vitalitet. Stockholm: Bröderna Lagerströms förlag.

Lagerkvist, P. (1915). Paul Cézanne. Första maj, p. 10-13.

Lagerkvist, P. (1916a). Om konsten. Några reflektioner. Folkkalendern, p. 71-81.

Lagerkvist, P. (1916b). Angest. Stockholm: Bonnier.

Lagerkvist, P. (1991). Brev. Urval av I. Schöier. Bonniers: Falun.

Lagerkvist, P. Kungliga biblioteket i Stockholm. L 120:79:2.

Lagerkvist, P. Kungliga biblioteket i Stockholm. Lagerkvist 1978/82.

Lagerkvist, P. Kungliga biblioteket i Stockholm. L 120:49:1.

Lagerkvist, P. Kungliga biblioteket i Stockholm. L 120:70.

Larsson, B. (1964). Den röda tiden och den rena konsten. Pär Lagerkvists litterära utveckling fram till Ordkonst och bildkonst. Samlaren, p. 19-39.

Linnér, S. (1954). Livsförsoning och idyll : en studie i rikssvensk litteratur 1915-1925. Uppsala: Uppsala Universitet.

Löwendahl, G. (1975). „Det yttersta ödet”. Kring några Lagerkvistmanuskript i Lund. In: R. Arvidsson et al. (eds.). Diktaren och hans formvärld (p. 119-131). Malmö: Allhem.

Ortega y Gasset, J. (1996). Dehumanizacja sztuki i inne eseje. Warszawa: MUZA S.A.

Sokel, W. (1964). The Writer in Extremis. Stanford: Stanford U.P.

Vattimo, G. (2006). Koniec nowoczesności. Kraków: Universitas.

\author{
Katarzyna Szewczyk-Haake \\ Uniwersytet im. Adama Mickiewicza w Poznaniu \\ Instytut Kultury Europejskiej \\ ul. Kostrzewskiego 5-7 \\ 62-200 Gniezno \\ Poland \\ haaczyk@amu.edu.pl
}

